\title{
Perception of the Local Population toward Urban Forests in Municipality of Aerodrom
}

\author{
Aneta Blazevska \\ University St. Kiril and \\ Metodij Skopje, \\ Faculty of Forestry \\ Skopje \\ Macedonia \\ ablazevska@gmail.com
}

\author{
Katerina Miceva \\ University St. Kiril and \\ Metodij Skopje, \\ Faculty of Forestry \\ Skopje \\ Macedonia
}

\author{
Biljana Stojanova \\ University St. Kiril and \\ Metodij Skopje, \\ Faculty of Forestry \\ Skopje \\ Macedonia
}

\author{
Makedonka Stojanovska \\ University St. Kiril and \\ Metodij Skopje, \\ Faculty of Forestry \\ Skopje \\ Macedonia
}

\section{Abstract}

Background and purpose: With the development of both society and economy, environmental issues have become a more popular topic. In recent decades both the role and perception of urban forests have changed regarding recreational and environmental aspects on both a local and global level. This coupled with urbanization places great importance on how people see and value the forests in an urban and peri-urban setting. Visitors are not a homogeneous category and hence have different needs and perceptions of urban and peri-urban green spaces. The study aims to understand the visitors 'perception from municipality Aerodrom towards urban forests and their recreational use, benefits, preferences and perception regarding management activities of urban forests.

Materials and methods: The method used for the research is qualitative with semi-structured questionnaire which was conducted face to face. Gathered data were analyzed by Excel and after that were presented in tables and graphs for better review of the results. The study area was municipality of Aerodrom which has the biggest space under urban forests per capita in Skopje.

Results and conclusions: Results have shown that all respondents have permanent residence in the municipality of Aerodrom, located in different settlements and with the length of stay mainly between 5 to 40 years. There is a dominance of female population and respondent's age over 40 in the research. Results also showed that the average number of visit in urban forests by respondents during the week is three times. Regarding the meaning and association of term urban forests, results showed that majority of respondents have a clear and concise perception, and mainly this term for them is association on park and greenery, a nice decorated environment and place for walk. When it comes to the way how current situation with urban forest can be improved almost all of the re- spondents highlighted it can be through the following things: maintenance of the urban forests by the public enterprises to be set on a much higher level, more trees and flowers to be planted, more toilets and playgrounds to be built, and local government to forbid companies of building apartments and houses close to the urban forests.

Keywords: urban forests, perception, local population, municipality, urban green space, peri-urban green space

\section{INTRODUCTION}

With the development of both society and economy, environmental issues have become a more popular topic. In recent decades both the role and perception of urban forests have changed regarding recreational and environmental aspects on both a local and global level. This coupled with urbanization places great importance on how people see and value the forests in an urban and peri-urban setting [1].

Urban sites are often harsh, characterized by many pressures and threats, from limited growing space to adverse climatic conditions and air pollution [2]. As a result of urbanization attention is being given to green areas in and around cities. Need for on-site recreation, place for passive and active refreshment from daily stresses is increasing thus, easy accessible nearby green areas in and around cities are good opportunity for recreational and refreshment activities of citizens. Urban forestry is one of the most used terms in relation to trees in or near the urban environment. An urban forest can be defined by its placement in or near urban areas and by its multi-functional aspects given shade, 
amenity values, etc. Therefore, urban forestry can be defined as: planning, design, establishment and management of trees and forest stands with amenity values, situated in or near urban areas [3].

Although there is no commonly accepted definition for urban forestry, a working definition may be "an integrated approach to the planting, care and management of trees and forests in and around the city to secure multiple environmental and social benefits for urban dwellers" [4]. Current thinking leans toward considering the urban forest as all trees and related vegetation in and around towns and cities [5].

"Near-town forests have high value because of recreational demand, familiarity of the forest to the people..." [6]. Most of the values attached to urban forests are non-priced environmental benefits that include e.g. pleasant landscape, ecological balance, pollution control, climatic and physical benefits, peace and quiet and potential recreation opportunities [7].

Urban forestry is a new concept in SEE region. Relatively little has been written about urban forestry, so there is need for more comparative information on what modes of urban forest governance exist and how they work [8]. Definitions of the (peri-) urban forest (hereafter referred to as the 'urban forest' for reasons of simplicity) itself include all the trees and woodland in - and around - urban areas [9]. "Urban Forestry means planning, establishing, protecting, and managing of trees and associated plants, individually, in small groups, or under forest conditions within cities, their suburbs, and towns" [4]. USDA Forest Service guidance amplifies this, defining the management of the urban forest as the "planning for and management of a community's forest resources to enhance the quality of life. The process integrates economical, environmental, political and social values of the community to develop comprehensive management plan for the Urban Forest"[4].

Trees and forests are, because of seasonal changes and their size, shape, and color, the most prominent elements of urban nature. Their benefits and uses range from intangible psychological and aesthetic benefits to amelioration of urban climate and mitigation of air pollution. Historically the main benefits of urban trees and forests relate to health, aesthetic and recreational benefits in industrialized cities. Moreover, green areas have provided people with subsistence by providing food, fodder, fuel, wood and timber for construction [10].

While these benefits of urban woodland, other tree stands and individual trees are not new they are still insufficiently recognized in urban planning and development processes. There is need to provide more knowledge on the role of urban woodland and trees in improvement of the environment and relate this to their social functions such as fostering mental and physical health. Urban forests, trees and other green spaces are thought to contribute significantly to certain psychophysical and social needs of urban dwellers. Recent studies on citizens' perceptions and behavior toward urban green areas have shown the complexity and the multidimensional character of the man-nature relationship in the city; inhabitants' use of green spaces appears to be motivated by the need for psychological health with relevant social implications [11].

\section{PROBLEM STATEMENT}

Visitors are not a homogeneous category and hence have different needs and perceptions of urban and peri-urban green spaces. In the recent years, South Eastern Europe (SEE) countries are facing with dynamic changes. Transition from socialism to democratic governance, fast growth of the population in the cities, urbanization and industrialization leads to changes in social and cultural lifestyle of citizens. Urbanization is ongoing process throughout the world especially in developing countries. The human population has lived a rural lifestyle through most of history. The world's population is quickly becoming urbanized as people migrate to the cities. In 1950, less than $30 \%$ of the world's population lived in cities. This number grew to $47 \%$ in the year 2000 ( 2.8 billion people), and it is expected to grow to $60 \%$ by the year 2025 [12].

Skopje, the capital city of Macedonia has a very long history as a main settlement in the Balkan region. Over the years, and influenced by many different and shifting regimes and cultures, the town has turned into a multifaceted and vibrant city, where a mixture of ethnic and socio-economic groups gives the city a specific character. Population increase in parity with the global urbanization trend and the simultaneous growth and shifts in the economy of the area has put a pressure on the socio-economic and environmental conditions under which the people live. According to last Census (2002), City of Skopje has 506926 inhabitants and this number rapidly grow. It is estimated that nowadays Skopje has around 1 million citizens [13].

With the high level of urbanization in Skopje, green areas in and around city are of great importance as recreational settings for urban dwellers. Environment in and around Skopje has become more and more polluted, life in the City become more stressed. It makes working people feel exhausted; nervous thus need more clean air, peace and recreation. Hence, parks, green spaces and trees are more than the "lungs 
of the city" or air pollution cleaners. They affect human health in a variety of ways such as active lifestyles, improved wellbeing, activities and emotional and physical health.

Study or research toward perception of the local population of municipality Aerodrom toward urban forests is not done yet, thus this research will provide (answers) information's on what are the visitors perception towards this area which will be helpful for the future development of the area. For many people, direct and indirect contact with nature is an essential aspect of their quality of life. Failures to understand how people experience and value nature can lead to misunderstanding between managers and public. Hence this research will help managers to understand and take into account the less tangible values that people derive from contact with nature. Taken into account above mentioned, it is necessary to know who, why and how use the urban forests - park in order to meet needs of the visitors.

Aerodrom is a municipality with the highest percentage on green space per capita, data from municipality show that it has $28 \mathrm{~m}^{2}$ of green space per capita, while according to the European standards this green space should be at $8.5 \mathrm{~m}^{2}$ per capita [14]. Currently the municipality builds new green spaces and parks in settlements Micurin, Lisice and regional centre of Aerodrom. For the maintenance of the green space, municipality use the services of public enterprise in Skopje - PE "Communal Hygiene" and PE "Parks and Greenery". In addition to better hygiene and maintenance of the green spaces, municipality hires seasonal workers [15]. Also, the municipality has purchased machinery (lawn mowers) tools and other equipment needed for that purpose. Maintaining hygiene of the green spaces municipality is conducting with the help of the public enterprises, with certain omissions, through its points. Local government is also working intensively on their urban documentation as a condition for sustainable development, quality of life and attracting investment [15]. All this is very important for the local population, science, public undertakings, parks and greenery.

\section{OBJECTIVE OF THE RESEARCH}

Research is focused on visitor's perception of urban forests in municipality of Aerodrom in everyday life - how local population, as direct users of the area, perceives urban forests in Aerodrom. The goal of research is to explore and describe opinions of the local population on the benefits of urban forest, variations in preferences and perceptions, recreational use of urban forest, perception and level of satisfaction of maintenance and management activities in the urban forests to policy makers who may be able to make changes to preserve and improve those areas.

In order to achieve the goal of the research, general objective of the study is to understand the perception of local population toward urban forests, though setting overall research question:

- What is the perception of the local population in municipality of Aerodrom toward urban forest in their place of living?

- What should be done in order to be improved management of urban forests in the municipality of Aerodrom?

\section{THEORETICAL FRAMEWORK}

In recent years, urban forest managers have been caught between the increasing demand for aesthetic and recreational use of urban forest resources and the decreasing budgets for managing those resources. This dilemma has created a need for more efficient ways to manage urban forests for the benefit of urban residents. In response to this need, the social science and design disciplines have undertaken studies of the human perceptual and behavioral aspects of the urban forests [16].

Perceptions and preferences from urban forests by Schroeder [16] are derived into following aspects:

- Benefits of urban forest vegetation,

- Preferences and perceptions,

- Safety,

- Variation in perceptions and preferences,

- Recreational use of urban forests,

- Applications of research.

Benefits of urban forest: Vegetation can have beneficial effects on people's moods and emotional states. The perceived benefits of urban forests generally fall into two main categories: benefits involving aesthetic enjoyment and relaxation; and benefits involving sports and social contact [2]. Coles and Bussey [17] recorded that $80 \%$ of visitors felt "close to nature", "relaxed" and/or "happy" when in the forest. Very few in their study felt anxious or insecure although Schmithusen and Wild-Eck [18] reported figures as high as $15 \%$ of all visitors feeling "unsafe" in other forests.

Preferences: Environmental perception studies seek to identify the characteristics and features that enhance the perceived quality of urban forests. In general, natural elements such as trees and water in landscapes are highly preferred over artificial elements. Trees and forested areas, water, good maintenance, and peace and quiet were among the most preferred features of urban parks and forests in several studies. The most 
widely preferred kind of park environment seems to be a well-maintained open stand of large trees with evenly mowed grass and water. Features that detract from the attractiveness of a park include manufactured objects (e.g. buildings, fences, and parking lots), poor condition of vegetation, urban surroundings adjoining the park, litter, graffiti, crowding, and large, monotonous fields. Either too many or too few trees in a park can reduce visual preference. Sounds that are incongruous with the character of the setting can also make a forest or park less attractive [19].

Safety: The probability of being a victim of crime is higher in cities than in non-urban areas. Despite large variations between regions, countries and cities, recent years show a widespread increase in urban violence worldwide, including homicide, assault, rape, sexual abuse and domestic violence [20]. Some urban parks, according to Wekerle and Whitzman [21] have become 'hot spots' of crime and other criminal activities like drug dealing, bashing and sexual violence. Crime and social conflict are a serious concern in some urban parks and forests. "Many park users are unwilling to use areas of a park they perceive as unsafe and many potential park users are deterred from using parks at all due to fears for personal safety" [22]. Social conflict includes a wide range of behaviors, from violent crimes to "nonviolent" offenses such as drug use, to behaviors that, although not illegal, may be threatening or offensive to other users [23].

Variation in preferences: Not everyone likes the same kind of places. There are variations in urbanites' perceptions of urban forest settings, especially with respect to the degree of naturalness versus development. Schroeder and Anderson [24] found that most of the participants in their research thought that natural-appearing parks with dense vegetation were the most attractive, but a few people preferred highly developed, "manicured" parks.

Recreation use: People's preferences for urban forest environments are expressed in their choices of which sites to visit and how to use those sites. Konijnendijk's study [25] showed that urban forests are highly valued and appreciated for their recreational potential. Some recreational activities seem to be popular in almost all urban forests, such as going for a short walk, jogging and walking the dog. These mostly concern daily, short-time use by people living nearby. In Britain, for example, urban forests often include golf courses, while cycling is very popular in the Netherlands and Denmark. In the Nordic and Eastern European countries in particular, skiing is a main use in winter, and the collection of berries and mushrooms in summer and autumn. In former East-Berlin, overnight stays in tents in the forests used to be very popular and is still practised, even after the reunification of the city and being illegal. Nature-oriented forms of recreation seem to be preferred, although this trend is stronger in some countries than in others. Another general development is the emergence of more active forms of recreational use, such as mountain biking [26].

Applications of research: Research on urban forests is useful only to the extent that it can contribute to the planning and management of vegetation in cities. In this section, research can provide information on how visitors perceive the importance of management objectives and the performance of the manager in meeting those objectives. Research will be used to document the importance of Park Forest to citizens, what services should be provided, and to reveal sources of dissatisfaction with tree management programs.

\section{METHODOLOGY}

When social research is conducted, certain methods and methodologies for producing scientifically based results have to be applied. The method used for conducting the research is qualitative. In order to explore and describe social and aesthetic benefits of urban forests and discuss how local population perceive these benefits, urban forests in municipality Aerodrom are used as a case study. Aim of the research is to gain insight in perception, preferences and demands/needs of local population in municipality of Aerodrom toward urban forests as well as their habits and motivation related to visiting urban forests (e.g. sports, relaxation, etc.). Deductive approach is applied beginning with abstract thinking, logically connecting ideas in theory to concrete evidence and testing the ideas against evidence. Surveys have been conducted in-person contact by the 'next-topass' technique [27], the sequential interview of a person or a group passing by. If a group was approached, the researcher attempted to make eye contact and responded to those who made eye contact.

The research was focused on fix settlements in the municipality of Aerodrom or in the larger parks in the municipality. Municipality of Aerodrom covers an area of $21.85 \mathrm{~km}^{2}$ and population of 98382 inhabitants. The whole area of the municipality or about $804519 \mathrm{~m}^{2}$ are green space [14].

The method of data collection were interviews "face to face" with half- structured questionnaire, which consisted of six closed and nine open-ended questions. In collection of data were interviewed 65 respondents, who were meet directly in the urban forests and were chosen by the method next to pass. The interviews were done over two days during the week, in the morning and in the evening during the day, in October 2012. Data have been analyzed in Excel and then presented in graphs and tables. 


\section{RESULTS}

After completion of survey and analysis of the primary data, in order to be examined and evaluated perception on the local population from municipality of Aerodrom toward urban forests following results has been obtained.

All $(100 \%)$ of the interviewed respondents (Figure 1) that took part in survey had a permanent residence in the municipality Aerodrom. Regarding in which part of municipality Aerodrom respondents are living (Figure 2), results showed that $29.6 \%$ were located in settlement Aerodrom, 27.6\% are living in Novo Lisice, $18.4 \%$ of respondents answered that they live in settlement Lisice, after them with $13.8 \%$ follow respondents from Micurin, while $7.6 \%$ from respondents live in settlement Ostrovo, and only $3.0 \%$ of respondents are located in settlement Old Aerodrom.

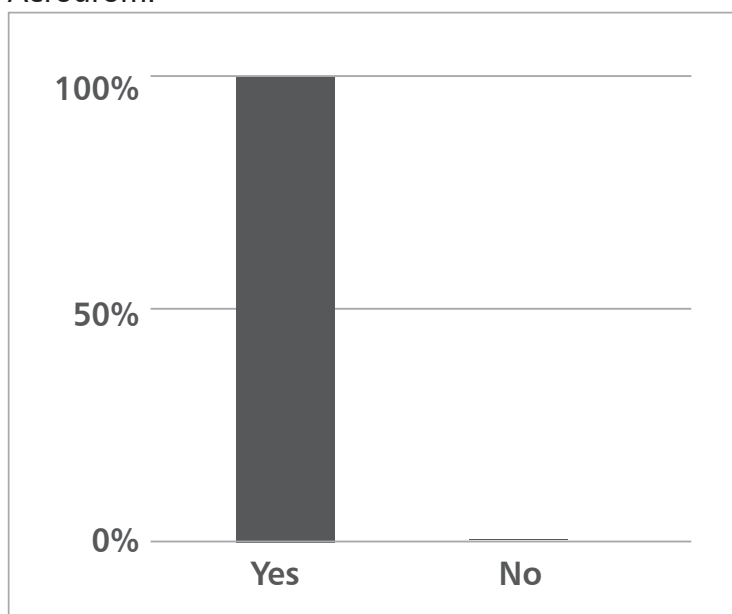

\section{FIGURE 1}

Q1: Is this your place of living?

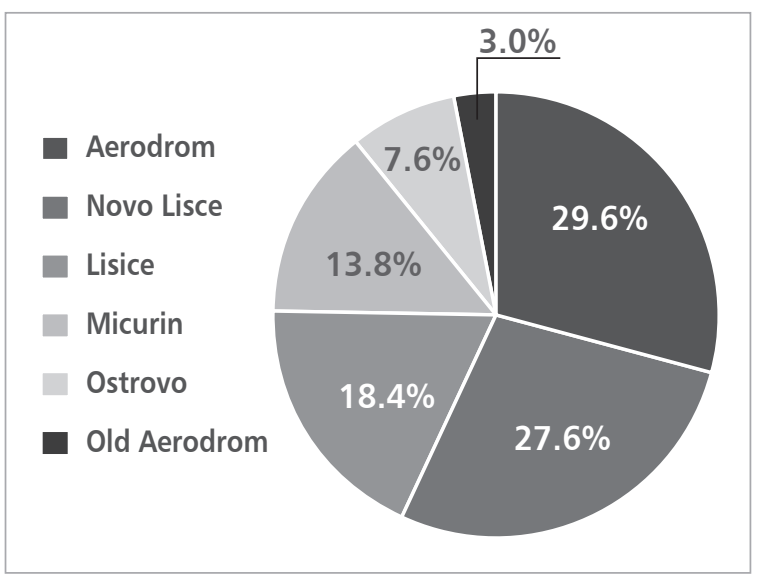

FIGURE 2

Q2: In which part of municipality do you live?
In terms of how long respondents live in their settlements (Figure 3), results gained from the research showed that nearly half or $41.5 \%$ from respondents answered that duration of their stay in that settlement is between $21-40$ years, close to this percentage or around $36.9 \%$ of respondents are with period of living between 5 20 years, with $16.9 \%$ are respondents which period is more than 41 years, while only small \% or around $4.7 \%$ belongs to the respondents which period of living is less than 5 years.

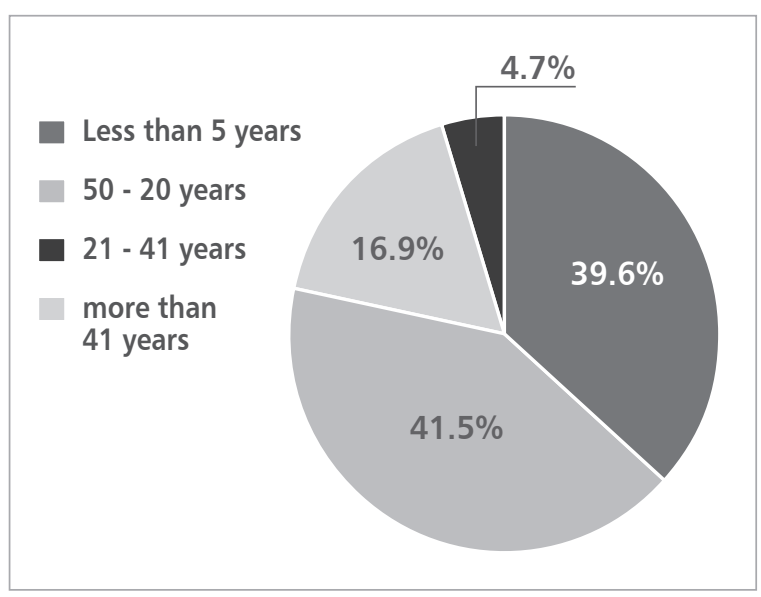

FIGURE 3

Q3: How long do you live here?

$100 \%$

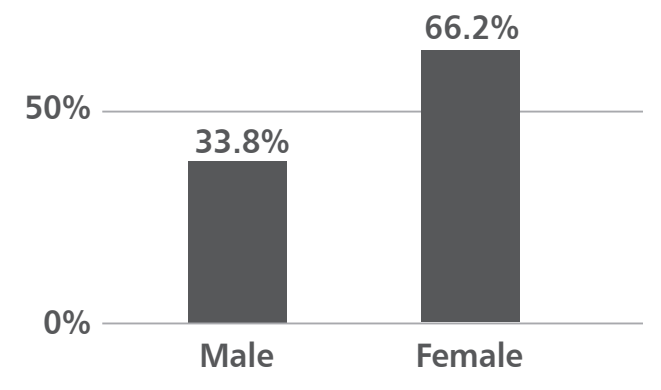

\section{FIGURE 4}

Q4: What is your gender?

Regarding the gender of respondents that took part in research, results showed (Figure 4) that involvement of both genders is not the same or female population with $66.2 \%$ is dominating over the male population which participated in the research with only $33.8 \%$. When it comes to maturity or age structure of respondents that were included and participated in the survey according 
to the obtained results, the age structure of respondents was divided into four categories. First category includes all respondents younger than twenty years, the second is between twenty one and forty years, the third class is from forty one to sixty while in the fourth class are respondents older than sixty one. As it can be seen and concluded from the (Figure 5), the biggest share (50.7\%) in the survey has respondents from forty one to sixty years, while the respondents over sixty one have only $12.3 \%$. It means that $73 \%$ of the respondents involved in the survey belong to the category over forty years. While only $27.7 \%$ of the interviewed respondents belong to the category from twenty one to forty, and $9.3 \%$ goes to the age under twenty. Hence the average maturity of respondents is 44.5 years.

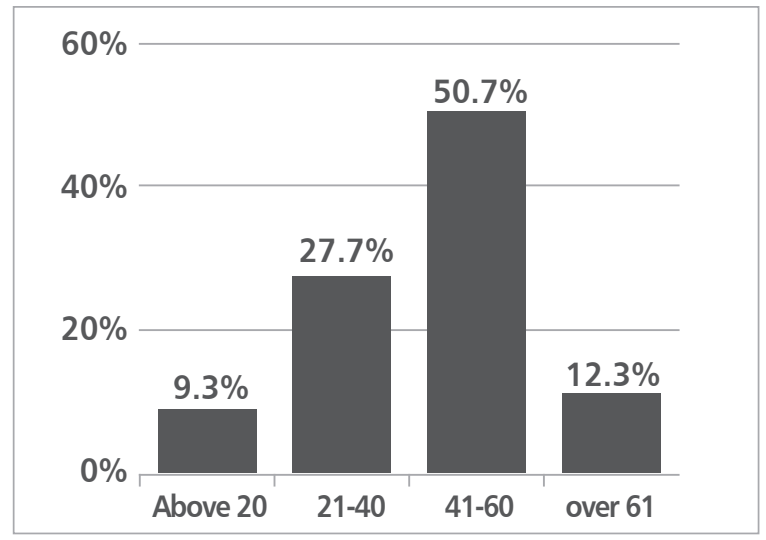

FIGURE 5

Q5: How old are you?

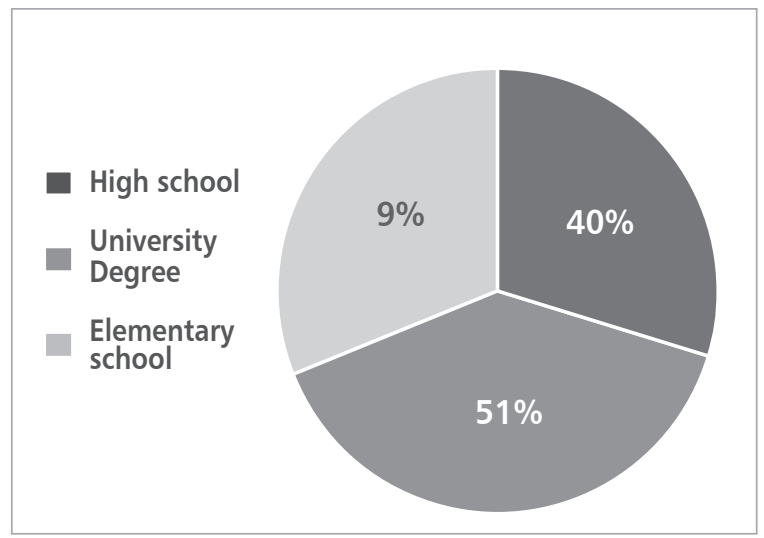

\section{FIGURE 6}

Q6: What is your education?

In terms of education level of the respondents that participated in research results showed that the largest percentage (51\%) from respondents are with university degree, with high school have around $40 \%$ and only $9 \%$ of respondents answered that they have other education level (Figure 6).

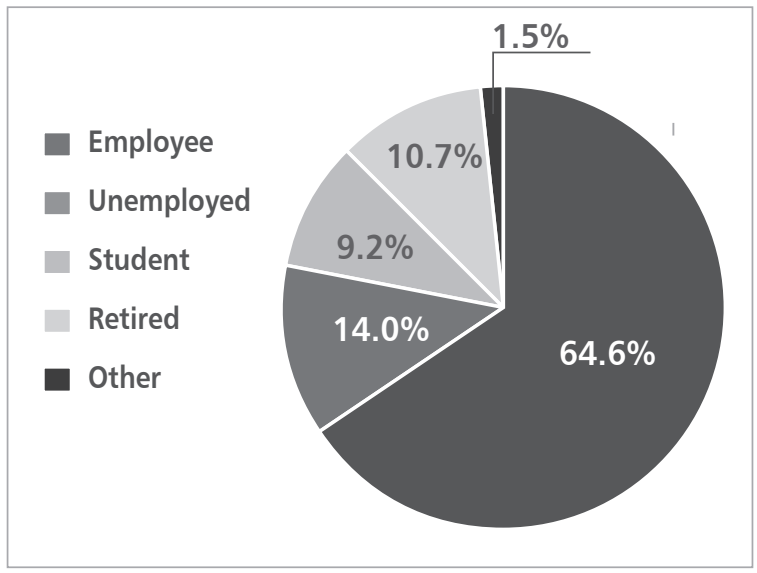

FIGURE 7

Q7: What is your occupation?

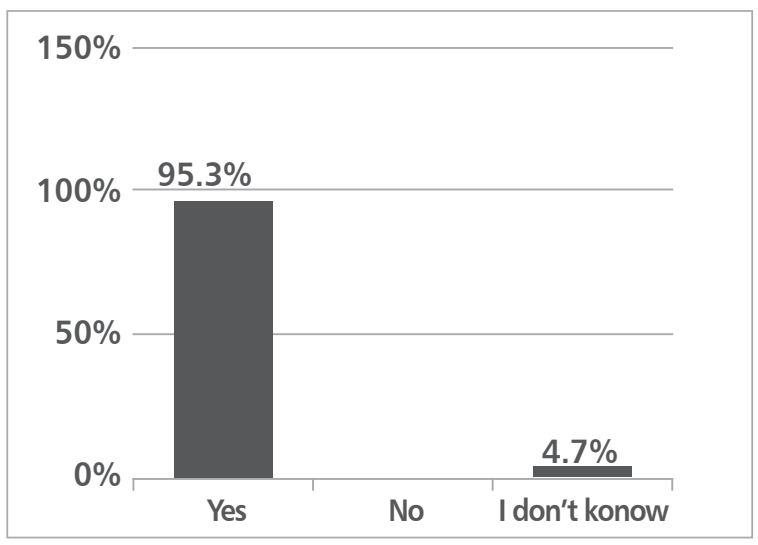

FIGURE 8

Q8:Are you familiar with the term urban forests?

The biggest part $(64.1 \%)$ in the research took respondents (Figure 7) who are employed, after that following were unemployed respondents with $14.0 \%$, while retired people participated with $10.7 \%$, with a slightly lower percentage (9.2\%) were students, and only $1.5 \%$ of the participants belong to the group of others. Regarding familiarity of respondents with the term urban forests, research obtained following results. Interesting is to highlight the fact that almost all $(95.3 \%)$ of respondents are familiar with the term urban forests, while only $4.7 \%$ dont know right meaning of this term, and what makes things really interesting is that not even one of respondents answered that is not familiar.

When all respondents that took part in the research were asked to explain on what associate them the term urban forests, almost half of them (47.6\%) pointed out that is park and greenery. Around $15.3 \%$ of respondents stressed that this term associate them on a nice decorated environment, while for about $10.7 \%$ this term mean a 


\section{On municipality Aerodrom}

Playgrounds

Place where I can walk with my dog

A nice place for relaxation and walk

Clean environment with trees,...

\section{FIGURE 9}

\section{Q9: On what you become associated with the term urban forests?}

nice place for relaxation and walk. For $9.6 \%$ this term is association of a clean environment with trees, grass and flowers, while for smaller percentage or for about $7.6 \%$ the term associate them on a playgrounds, some $(6.1 \%)$ are associated with the municipality Aerodorm and for the smalest percentage of respondents (3.1\%) this term associate them on a place where they can take a walk with their dog. Results from the research also showed that number of visits in the urban forests among respondents vary greatly starting from once per a week till seven times per a week. Hence average number of visit on local population to the urban forests is three time per a week.

Regarding the main reasons why respondents visit urban forests, according to the gained results more than a half of respondents $(53.8 \%)$ highlight because

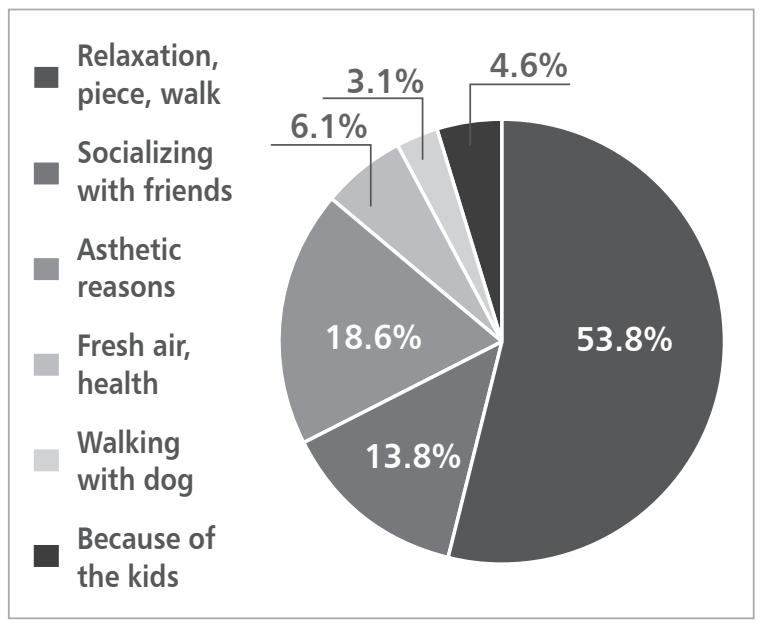

\section{FIGURE 10}

Q10: What are the reasons why you visit urban forests? these places offer them relaxation,piece, and walk, while $18.6 \%$ visit urban forests because of aestethic reasons. Around $13.8 \%$ visit urban forests in order to socialize with their friends, some $(6.1 \%)$ of respondents state that they visit them because of the fresh air and health, while for a small percentage of them (4.6\%) reason is their walk with the kids and for $(3.1 \%)$ is walk with the dog.

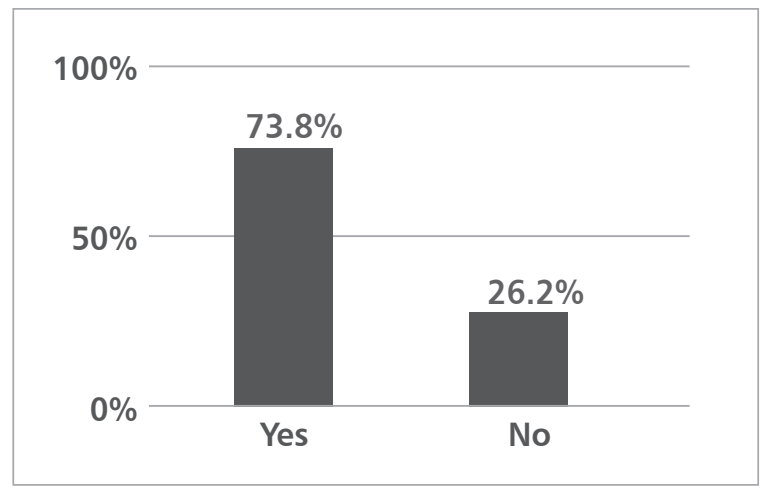

FIGURE 11

Q11: Are you satisfy with the current

When it comes to how respondents are satisfy with the current situation of urban forests in their place of living (Figure 11) according to the results majority of respondents $(73.8 \%$ ) are satisfy while only $22.2 \%$ think that situation should be better and is not on a satisfactory level. Regarding the needs of new urban forests at their place of living (Figure 12) results showed that according to the opinion of majority of respondents $(80 \%)$ there is a need for new urban forests, while $20 \%$ don't share the same opinion so they stressed that those surface under urban forests are enough to meet the needs of the local population from municipality Aerodrom. 


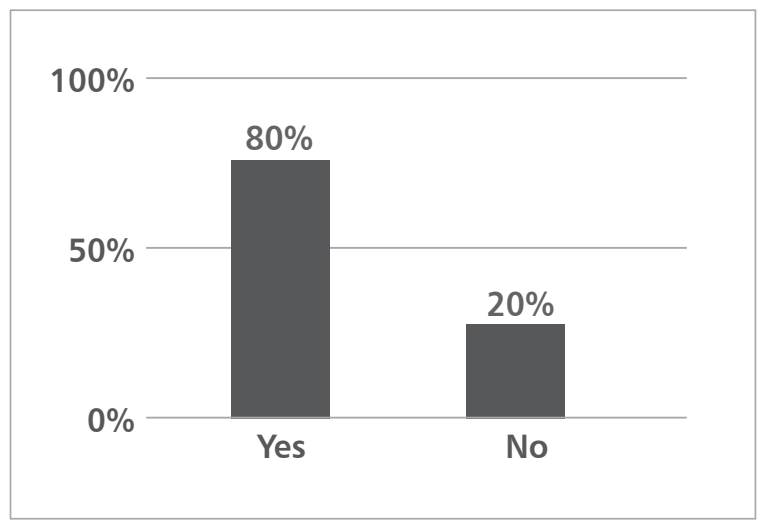

\section{FIGURE 12}

Q12: Do you think there is a need for new situation of urban forests?

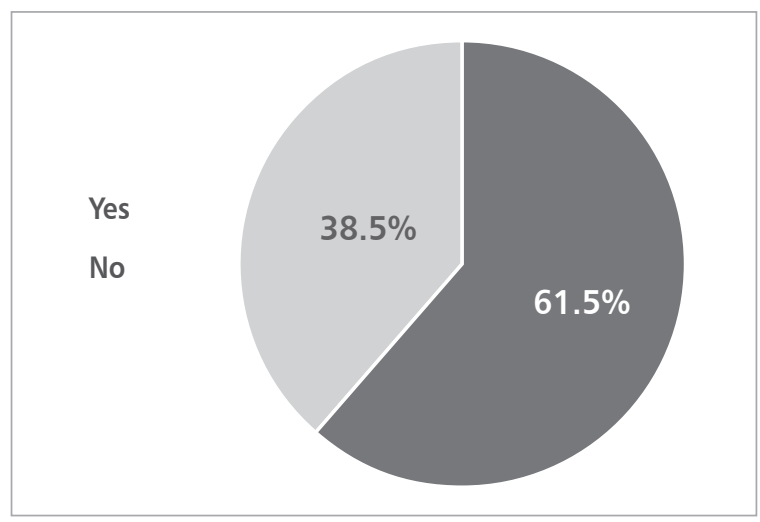

\section{FIGURE 13}

Q13:Do you think something should be improved regarding the urban forests in your area?

Opinion among respondents in terms of whether something should be change or not in terms of urban forests in their region differs (Figure 13). Thus 61.5\% of respondents said that according to them there are many things that should be changed in urban forests in their region, while $38.5 \%$ do not share same opinion because according to them there is no need for any change at all. According to the respondents perception following things should be done in order the complete situation with urban forests to be improved in their place of living. Thus as one of the most important or with $26.3 \%$ is maintenance of the urban forests to be on a much higher level than it is the moment. While $24.6 \%$ from respondents think that situation will be improved if there will be planted more flowers and trees, and at the same time to be built more toilets and plagrounds. Contrary to those respondents $18.4 \%$ stressed that according to them nothing should be changes or improved for now because everything is ok. But for $13.8 \%$ there is a space and needs for more urban

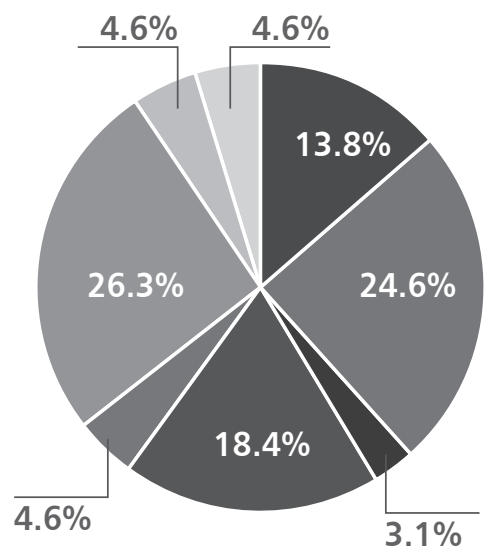

One the place of urban forestes not be built any other buildings

Maintainance to be on a higher level then now

To have separated places for dogs

\section{FIGURE 14}

Q14: What should be done and improved regarding the urban forests in your area?

forests in this municipality and that can help a lot in improvement of the current situation. While according to $4.6 \%$ of respondents there is a need for more space for kids, on the place of the urban forests to not be built any other facilities, and to have separated place for dogs. And at the end only $3.1 \%$ pointed out that according to them urban forests should be set on a higher distance from the traffic.

\section{DISCUSSION AND CONCLUSSIONS}

This research gives an general understanding on perception of the local population toward urban forests in municipality Aerodrom. With alteration on lyfestyles of local population and modernazation of the world, needs and demands for urban forests had changed a lot and become more diverse. Although urban forests often can be places which bring people with different social and cultural background to socialize together, still many of the residents are seeing urban forests as a pieceful and quite place for their relaxation. However awarness of the importance on ecology, preserving and improving the urban forests benefits is constantly increasing among local population. For many people, their direct or indirect contact with nature play very important role for the quality of their life. Inability to precisely understand how people perceive and value urban forests might lead to misunderstandings between managers and users [10]. 
Obtained results from the research clearly indicate that all of respondents have a permanent residence in the municipality of Aerodrom, but located in different settlements and parts. Length of the stay in their place of residence for majority of respondents $(78 \%)$ that took part in the research is between 5 to 40 years, while a smaller percentage refers to those respondents who have either less than 5 or more than 41 years. When it refer to gender involvement in the research, results shown that there is a significant predominance of female over male population, and also a predominance of respondents (73\%) over 40 years. Taking into account the educational level of respondents $(90 \%)$ which have either high school or university degree than its not suprising the result that almost all $(95.3 \%)$ of respondents are familiar with the term urban forests. On top of this if is add the fact that average number of visit by local population is three times per a week according to the results from the research than its not suprising again very high percentage of local population with the familiarity of the term urban forests. Regarding on which things are associated with the term urban forests, results from the research showed that majority of respondents (74\%) stressed that these things are: park and greenery, a ni- ce decorated environment and a place for relaxation and walk. Although opinions among respondents vary about the reasons why they visit urban forests, yet majority of the respondents $(73 \%)$ pointed out that the main reasons why they visit urban forests are: relaxation, piece, walk and also aestethic. Its intresting to highlight that majority (73.8\%) of respondents are satisfy with the current situation of the urban forests in their municipality, and only small percentage express their dissatisfaction regarding the current situation. Although majority (80\%) of respondents are satisfied with the current state of urban forests, yet they think that there is a space and need for new urban forests in their place of living. Intresting is to highlighgt that although majority $(73.8 \%)$ of respondents are satisfy with the urban forests in their municipality still for more than a half something should be done regarding this areas. As some of the things that have been mentioned and pointed out by the respondents which can help in improvements of the current situation with urban forests are: maintenance of the urban forests to be on a much higher level, to be planted more trees and flowers, to be built more toilets and plagrounds, as well as to not be built any other buildings close at the place where are located urban forests.

\section{REFERENCES}

1. DAVID D V 2002 Surveys in Social Research. 5th Edition, Routledge, p 379

2. KONIJNENDIJK C C, RICARD R M , KENNEY A, RANDRUP T B 2006 Defining urban forestry- A comparative perspective of North America and Europe. Urban For Urban Gree 4 (3-4): 93-103

3. COST Action E12, Urban forests and trees, Technical annex. Available at: http://www.consilium.europa.eu/ ueDocs/cms_Data/docs/dynadoc/out/cost/en/COST_AT_ E12.PD (Accessed: 15 October 2012)

4. MILLER R W 1997 Urban forestry: planning and managing urban green spaces. 2nd Edition, Prentice Hall, New Jersey, pp 31-35

5. BISTA R 2009 Institutional involvement and peoples' perception towards urban forestry, A case Study of Lalitpur Sub-metropolitan City. A. B.Sc. Forestry Research Thesis Submitted to Tribhuwan University, Institute of Forestry, Pokhara, Nepal, p 46

6. PEARCE D W 2011 The Economic Value of the Forest Ecosystems. Ecosyst Health 7 (4): 284-296

7. ROBINETTE C, GARY O 1972 Plants People and Environmental Quality. USA department of the Interior, National Park Service, Publisher: Washington DC

8. BENTSEN P, LINDHOLST A C, KONIJNENDIJK C C 2010 Reviewing eight years of Urban Forestry \& Urban Greening: Taking stock, looking ahead. Urban For Urban Gree 9 (4): 273-280
9. LAWRENCE A, JOHNSTON M, KONIJNENDIJK C C, VREESE R D 2011 Briefing paper 3: The governance of (peri-) urban forestry in Europe. Presented at Workshop on sharing experiences on urban and peri-urban forestry, Brussels, 28th January 2011

10. Available at: http://ec.europa.eu/agriculture/fore/events/28-01-2011/lawrence en.pdf (Accessed: 20 October 2012)

11. TYRVÄINEN L, PAULEIT S, SEELAND K, VRIES S 2005 Benefits and uses of urban forests and trees. In: C.C. Konijnendijk, K. Nilsson, T.B. Randrup and J. Schipperijn, Editors, Urban Forests and Trees, Springer, Berlin. Chapter 4

12. SANESIA G, CHIARELLOB F 2006 Residents and urban green spaces: The case of Bari. Urban For Urban Gree 4 (3-4): 125-134

13. URBANIZATION AND GLOBAL CHANGE 2006. Available at: http://www.globalchange.umich.edu/globalchange2/ current/lectures/urban_gc/ (Accessed: 12 October 2012)

14. Census of population households and dwellings in the Republic of Macedonia 2002 State statistical office Republic of Macedonia (Accessed: 14 October 2012)

15. NOVA MAKEDONIJA 2012. Available at: http://www. novamakedonija.com.mk/NewsDetal.asp? vest $=71$ $312911434 \&$ id $=14 \&$ prilog $=0$ \&setlzdanie $=22629$ (Accessed: 10 November 2012)

16. OPŠTINA AERODROM 2009. Available at: http://www. aerodrom.gov.mk/tl_files/aerodrom/vesnik_pdf/leap. pdf (Accessed: 14 October 2012) 
17. SCHROEDER H W 1989 Environment, behavior, and design research on urban forests. In E H Zube, G T Moore (eds.), Advances in environment, behavior, and design, vol. 2. New York: Plenum

18. COLES R W, BUSSEY S C 1999 Community forestry in an urban context-progressing the social agenda conference paper. In Community Forestry, a Change for the Better, Countryside Agency, Guildhall, London,7-8 December

19. SCHMITHUSEN F, WILD-ECK S 2001 Uses and perceptions of forests by people living in urban areas: findings from selected empirical studies. Forstwissenschaftliches Centralblatt 119: 395-408

20. HERBERT W S 1990 Perceptions and preferences of urban forest users. Journal of Arboriculture 16 (3): 58-61

21. UN-HABITAT 2004 The state of the world's cities 2004/2005 Globalization and urban culture. United Nations Human Settlements Program (UN Habitat). Available at: http://www.unhabitat.org (Accessed: 5 October 2012)

22. WEKERLE G, WHITZMAN C 1995 Safe cities: Guidelines for planning, design and management. New York: Van Nostrand Reinhold
23. MARCUS C C, FRANCIS C A 1998 People Places: Design Guidelines for Urban Open Space, Published: John Wiley \& Sons, New York

24. CHUBB M, T N WESTOVER 1980 Antisocial behavior: typology, messages, and implications for recreation resource managers. In Proceedings of LandUse Allocation: Processes, People, Politics, Professionals (Spokane, WA)

25. SCHROEDER H W, ANDERSON L M 1984 Perception of personal safety in urban recreation sites. Leisure Research 16 (2): 178-194

26. KONIJNENDIJK C C 1999 Urban forestry: comparative analysis of policies and concepts in Europe. Contemporary Urban Forestry Policy-Making in Selected Cities and Countries of Europe. Working Paper 20. European Forest Institute, Joensuu, Finland, 1999, p 266

27. HUNTER I R 2003 What do people want from urban forestry? - The European experience. Urban Ecosyst 5 (4): 277-284

28. SEGEREN A J H, VISSCHEDIJK P A M 1997 Het recreatief gebruik van SBB-terreinen in de regio Brabant-West, IBN-rapport no. 264. IBN-DLO, Wageningen 